 \\ OF MEDICAL AND BIOLOGICAL RESHARCH \\ www.bjournal.com.br
}

ISSN 0100-879X

Volume 45 (2) 93-178 February 2012

BIOMEDICAL SCIENCES

AND

CLINICAL INVESTIGATION

Braz J Med Biol Res, February 2012, Volume 45(2) 125-130

doi: 10.1590/S0100-879X2011007500163

\section{Viability of mesenchymal stem cells during electrospinning}

G. Zanatta, D. Steffens, D.I. Braghirolli, R.A. Fernandes, C.A. Netto and P. Pranke

The Brazilian Journal of Medical and Biological Research is partially financed by

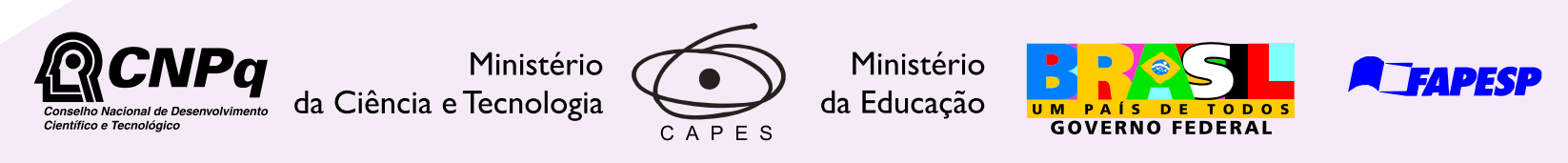

Institutional Sponsors
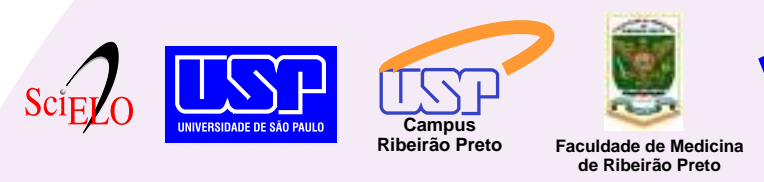

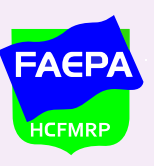

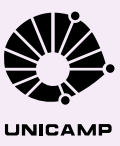

Ф SHIMADZU

A대맘

Associaçăo
Fundo de Incentivo
à Pesquisa

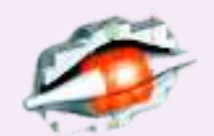

UNICAMP

lore High - Performance MS Orbitrap Technology analitica Thermo 


\title{
Viability of mesenchymal stem cells during electrospinning
}

\author{
G. Zanatta ${ }^{1,2 *}$, D. Steffens ${ }^{1 *}$, D.I. Braghirolli ${ }^{1}$, R.A. Fernandes ${ }^{3}$, \\ C.A. Netto ${ }^{2}$ and P. Pranke ${ }^{1,4}$ \\ ${ }^{1}$ Laboratório de Hematologia e Células-tronco, Faculdade de Farmácia, \\ Universidade Federal do Rio Grande do Sul, Porto Alegre, RS, Brasil \\ ${ }^{2}$ Laboratório de Isquemia Cerebral, Departamento de Bioquímica, \\ Universidade Federal do Rio Grande do Sul, Porto Alegre, RS, Brasil \\ ${ }^{3}$ Hospital Nossa Senhora da Conceição, Grupo Hospitalar Conceição, Porto Alegre, RS, Brasil \\ ${ }^{4}$ Instituto de Pesquisa com Células-tronco, Porto Alegre, RS, Brasil
}

\begin{abstract}
Tissue engineering is a technique by which a live tissue can be re-constructed and one of its main goals is to associate cells with biomaterials. Electrospinning is a technique that facilitates the production of nanofibers and is commonly used to develop fibrous scaffolds to be used in tissue engineering. In the present study, a different approach for cell incorporation into fibrous scaffolds was tested. Mesenchymal stem cells were extracted from the wall of the umbilical cord and mononuclear cells from umbilical cord blood. Cells were re-suspended in a $10 \%$ polyvinyl alcohol solution and subjected to electrospinning for 30 min under a voltage of $21 \mathrm{kV}$. Cell viability was assessed before and after the procedure by exclusion of dead cells using trypan blue staining. Fiber diameter was observed by scanning electron microscopy and the presence of cells within the scaffolds was analyzed by confocal laser scanning microscopy. After electrospinning, the viability of mesenchymal stem cells was reduced from 88 to $19.6 \%$ and the viability of mononuclear cells from 99 to $8.38 \%$. The loss of viability was possibly due to the high viscosity of the polymer solution, which reduced the access to nutrients associated with electric and mechanical stress during electrospinning. These results suggest that the incorporation of cells during fiber formation by electrospinning is a viable process that needs more investigation in order to find ways to protect cells from damage.
\end{abstract}

Key words: Nanotechnology; Tissue engineering; Electrospinning; Stem cells

\section{Introduction}

Tissue engineering is a growing field with the potential to regenerate damaged tissue (1-3). One of the most important goals in this area is to associate cells with biomaterials to provide a scaffold on which they can anchor, migrate and proliferate three-dimensionally. This approach has a great potential for many tissues such as vessels $(4,5)$, bone $(6,7)$, neural tissue $(8,9)$, cartilage $(10,11)$, and tendons/ ligaments $(12,13)$.

Among the various types of materials used in tissue engineering, scaffolds based on nanofibers produced by electrospinning have been widely studied. This technique is employed to produce nanofibers with a diameter in the range of nanometers to micrometers by the use of electrostatic forces. Many parameters are involved in the failure of the final fiber, such as the applied voltage, tip-target distance, feeding rate, concentration and viscosity of the polymer solution, and temperature, among others $(14,15)$.

Scaffolds produced by this method are porous and have a large surface-to-volume ratio. The mechanical properties of the scaffolds provide enough space to accommodate cells and an easy passage for nutrient intake and metabolic waste exchange (14). It is believed that fibers formed by electrospinning have the ability to mimic, in a limited way, the natural extracellular matrix structure regarding variability of fiber diameter, topology, texture, and mechanical properties (16).

Correspondence: P. Pranke, Laboratório de Hematologia e Células-tronco, Faculdade de Farmácia,

Universidade Federal do Rio Grande do Sul, Av. Ipiranga, 2752, Laboratório 304, 90610-000 Porto Alegre, RS, Brasil.

E-mail: patriciapranke@hotmail.com or patriciapranke@ufrgs.br

*These authors contributed equally to this study.

Received July 7, 2011. Accepted December 12, 2011. Available online December 23, 2011. Published February 17, 2012. 
Mononuclear cells (MNCs) including lymphocytes, monocytes and progenitor cells can be obtained from umbilical cord blood (UCB), together with a limited number of stem cells such as hematopoietic stem cells and, in lower quantities, mesenchymal stem cells (MSCs) (17-19). Another source of MSCs is the umbilical cord (UC) itself, which provides more cells than umbilical cord blood (20). Due to their ability for self-renewal and high proliferation capacity, MSCs are candidates for cell therapies to regenerate tissues and organs affected by various diseases, such as neurologic, rheumatic, cardiac, and autoimmune diseases, among others.

Although electrospun fibers of various polymers and different cell types have been brought into contact numerous times, the fibers are typically electrospun first and cells are seeded onto the material in a separate step (21-23). Due to the limitations of cell mobility or scaffold properties, such as low porosity, sometimes the thee-dimensional structure cannot be completely filled by biological material, compromising the structure and function of tissue formation.

In the present study, taking into consideration the process of co-electrospinning, attention was focused on cell incorporation into the scaffolds during nanofiber formation. The polymer of choice was polyvinyl alcohol (PVA), due to its low toxicity and high solubility in an aqueous medium. The viability of MSCs and MNCs after electrospinning was determined.

\section{Material and Methods}

\section{Isolation and characterization of MSC and MNC}

The study was approved by the Ethics Committee of the Hospital Moinhos de Vento (Process No. CEP/IEPAHMV 2006/42) and the Universidade Federal do Rio Grande do Sul (Process No. CEP/UFRGS 2006563) and three samples each of UCB and UC were obtained from the Centro Obstétrico do Hospital Moinhos de Vento after the mothers gave written informed consent.

UCB samples were obtained by puncture of the umbilical vein of the umbilical cords of neonates during normal or cesarean delivery and collected into bags containing citrate, phosphate, dextrose, and adenine (CPDA-1) as an anticoagulant. UC samples were collected by cutting the umbilical cord near the placenta following the procedure described by Secco et al. (20) and were kept in a growth medium (DMEM-low glucose, 10\% fetal bovine serum, $2 \mathrm{U} /$ $\mathrm{mL}$ penicillin, $2 \mu \mathrm{g} / \mathrm{mL}$ streptomycin, and $44.8 \mu \mathrm{g} / \mathrm{mL}$ gentamycin). Both the UCB and UC samples were transported to the laboratory and processed within $24 \mathrm{~h}$ post-delivery.

Separation of the MNC fraction from UCB. UCB samples were diluted 1:1 with PBS and MNCs were isolated by density gradient centrifugation at $1200 \mathrm{~g}$ for $20 \mathrm{~min}$ at room temperature using Ficoll-Paque (Sigma, USA) (24). MNCs were then washed twice with PBS and counted in a Neubauer chamber using 4\% Trypan blue for cell death exclusion.

MSC separation from UC. UC samples were incubated in $0.1 \%$ collagenase type I (Sigma) at $37^{\circ} \mathrm{C}$ for $15-20 \mathrm{~min}$. Detached cells were then harvested after massage of the $\mathrm{UC}$ with the aid of tweezers and centrifuged at $300 \mathrm{~g}$ for 10 min. Samples were re-suspended in a medium, seeded in $25-\mathrm{cm}^{2}$ flasks and kept at $37^{\circ} \mathrm{C}$ in a humidified atmosphere containing $5 \% \mathrm{CO}_{2}$. Non-adherent cells were removed after 24-h incubation; the culture medium was replaced every 3-4 days.

MSC culture and characterization. Adherent cells were cultured according to established norms $(25,26)$ and standard procedure of the laboratory (27). Passages were performed when cells reached $80-90 \%$ confluence at a split rate of $1: 3$. Cells used in the experiments were cultured until the fourth passage.

Flow cytometry was performed using a FacsCalibur instrument (Becton Dickinson, USA) equipped with an argon-ion laser tuned at $488 \mathrm{~nm}$ and the data were analyzed using the CELLQuest software (Becton Dickinson). The cells were incubated with antibodies for $30 \mathrm{~min}$ at $4^{\circ} \mathrm{C}$ and were then washed with PBS. 7-Aminoactinomycin D (7AAD; Molecular Probes, Inc., USA) at a final concentration of $1 \mu \mathrm{g} / \mathrm{mL}$ was used to identify dead cells. The following specific antibodies for the human antigens were purchased from PharMingen/Becton Dickinson, USA): CD29/PE, CD34/PE, CD44/FITC, CD45/FITC, CD90/FITC, CD117/ PE, CD133/PE, CD146/FITC, CD184/PE, HLA-DR/FITC, and Stro-1/FITC, as well as the isotype control antibodies mouse lgG1,k/FITC and IgG1,k/PE. The gating strategy was used in order to acquire 10,000 events corresponding to a live MNC cluster. In this gate, the analysis was performed to observe double labeling in this population using a combination of the other antibodies.

Mesenchymal differentiation capacity was determined as described by Meirelles and Nardi (28).

Adipogenic differentiation. MSCs $\left(2.0 \times 10^{4}\right.$ cells $\left./ \mathrm{cm}^{2}\right)$ were cultured in Iscove's medium supplemented with $20 \%$ human plasma $0.1 \mu \mathrm{M}$ dexamethasone, $0.44 \mathrm{mM}$ insulin, $5 \mu \mathrm{M}$ indomethacin, $5 \mu \mathrm{M}$ rosiglitazone, and $10 \mu \mathrm{M} / \mathrm{mL}$ sodium heparin. The medium was changed every 3 days. Adipogenic potential was determined after 21 days by the formation of intracellular lipid droplets demonstrated by oil red O staining (Sigma-Aldrich Ltd., USA).

Osteogenic differentiation. Cells were seeded at a concentration of $2.0 \times 10^{4}$ cells $/ \mathrm{cm}^{2}$ and cultured in a medium supplemented with $15 \mathrm{mM}$ HEPES, 10\% SFB, $10 \mathrm{mM}$ ß-glycerophosphate, $10 \mathrm{nM}$ dexamethasone, and $5 \mu \mathrm{g} /$ $\mathrm{mL}$ ascorbic acid 2-phosphate. The medium was changed every 3 days. To evaluate the potential of osteogenic differentiation, the cultures were washed with PBS and calcium deposition was assessed by alizarin red S staining.

Chondrogenic differentiation. Cells at concentrations of $2.0 \times 10^{4}$ cells $/ \mathrm{cm}^{2}$ were cultured in a medium consisting of 2,3-butanedione monoxime supplemented with $15 \mathrm{mM}$ 
HEPES, $1.09 \mathrm{mM}$ insulin, $10 \mathrm{ng} / \mathrm{mL}$ transforming growth factor- $\beta 1$ (TGF- $\beta 1$ ), and $50 \mathrm{nM}$ ascorbic acid-2 phosphate (AsAP). The medium was changed every 3-4 days and the cells were fixed on day 21 with $4 \%$ paraformaldehyde. Chondrogenesis was indicated by the deposition of a matrix, rich in glycosaminoglycan sulfate, stained by Alcian blue.

\section{Preparation of PVA solution}

An aqueous solution of $10 \%(\mathrm{w} / \mathrm{w})$ was prepared by mixing PVA (molecular weight: $3.44 \times 10^{6} \mathrm{~g} / \mathrm{mol} \pm 6.0 \%$ ) in Milli- $Q$ water and stirred at room temperature for $16 \mathrm{~h}$ to obtain a homogeneous solution.

\section{Preparation of the PVA-cell suspension}

MSCs were trypsinized, washed and quantified using a Neubauer chamber. Both MSCs and MNCs were re-suspended in a culture medium and an aliquot of 30 $\mu \mathrm{L}$ containing $1 \times 10^{6}$ cells was mixed with the PVA solution at a volume ratio of $1: 12$. The cells from the control group were re-suspended in a growth medium in the same proportions.

\section{Electrospinning}

Electrospinning was performed as described by Greiner and Wendorff (3). The PVA-cell suspension was stored in a 1-mL syringe with a hypodermic needle with an inner diameter of $0.45 \mathrm{~mm}$. The suspension was fed at a rate of $0.34 \mathrm{~mL} / \mathrm{h}$ through a syringe placed $15 \mathrm{~cm}$ from the collector plate and a voltage of $21 \mathrm{kV}$ was applied. Room temperature was $25^{\circ} \mathrm{C}$ and relative humidity $35-50 \%$. Nanofibers were collected on round glass coverslips placed on the ground collector. Fiber production was carried out for 30 min and all experiments were performed in triplicate.

\section{Characterization of nanofibers}

The morphology and diameter of the electrospun nanofibers were determined using a scanning electron microscope (SEM; JEOL - JSM 6060, JEOL Ltd., Japan). Samples collected on glass coverslips were mounted on an aluminum stub and sputter-coated with $15 \mathrm{~nm}$ carbon for analysis. Three SEM micrographs of distinct areas from each sample were used for analysis. Diameter analysis was performed by measuring the diameter of 30 fibers in each micrograph. The software used for the measurements and statistical analysis was ImageJ 1.38X.

\section{Cell viability analysis}

Cell viability was analyzed in three experiments carried out in triplicate in three distinct groups: 1) control: cells in growth medium at room temperature; 2) PVA: cells in a PVA solution at room temperature, and 3) electrospinning: cells electrospun in PVA solution. Cell viability was evaluated in all groups at the beginning of the experiments and after the electrospinning procedure.

Scaffolds produced in the electrospinning group were transferred to a flask containing culture medium in order to dissolve the fibers. The medium was added to the flasks of the control groups (cells in growth medium and cells in PVA solution) at the same proportion.

All samples were centrifuged at $300 \mathrm{~g}$ for $5 \mathrm{~min}$ at room temperature and the supernatant was removed. Cells were re-suspended in a medium and cell viability was determined using 4\% Trypan blue (Gibco, USA), in a 1:1 (v:v) ratio for dead cell exclusion.

\section{Cell incorporation into scaffolds during electrospinning}

The capacity of electrospinning to deliver cells among the fibers was assessed by cell nucleus staining with 0.2 $\mu \mathrm{g} / \mathrm{mL} 4$,6-diamidino-2-phenylindole (DAPI) for $20 \mathrm{~min}$. The suspension was then washed with PBS and centrifuged at $300 \mathrm{~g}$ for $10 \mathrm{~min}$. Fibers were collected on glass coverslips for $30 \mathrm{~min}$ and images were obtained by confocal laser scanning microscopy (Olympus FV-1000, Japan).

\section{Statistical analysis}

Cell viability was analyzed statistically using analysis of variance (ANOVA). Statistical analyses of groups of different cell types were performed by two-way ANOVA. All analyses were followed by the post hoc Tukey test for multiple comparisons when necessary. Data are reported as means $\pm S D$ and the level of significance was set at $P$ $<0.05$. All statistical analyses were performed using the Statistica ${ }^{\circledR}$ software package running on a compatible personal computer.

\section{Results}

\section{MSC characterization}

The characterization of MSCs follows criteria as established in the literature $(25,26)$ and standard laboratory procedures (27): 1) the cells were isolated for adherence in plastic and then proliferated in vitro; 2) they showed differentiation in adipocytes, osteoblasts and chondrocytes when submitted to differentiation assays, and 3) the cells demonstrated positive immunophenotypic profile for mesenchymal stem cells: CD90 (mesenchymal marker), CD29 and CD44 (adhesion markers), and negative for hematopoietic markers: CD45, CD34, CD117, and HLA-DR (data not shown).

\section{Effects of PVA and electrospinning on cell viability}

Fibers produced by electrospinning were smooth in appearance and free of beads, with an average diameter of $244 \pm 49 \mathrm{~nm}$ (Figure 1).

Exposure of the cells to a solution of 10\% PVA for the same amount of time as the electrospinning experiment resulted in significant effects on the viability of both types of cells. MNC viability was reduced from $99 \%$ in the control group to $80 \%$ when the cells were mixed with the PVA solution. The experiments using MSCs showed a reduction 

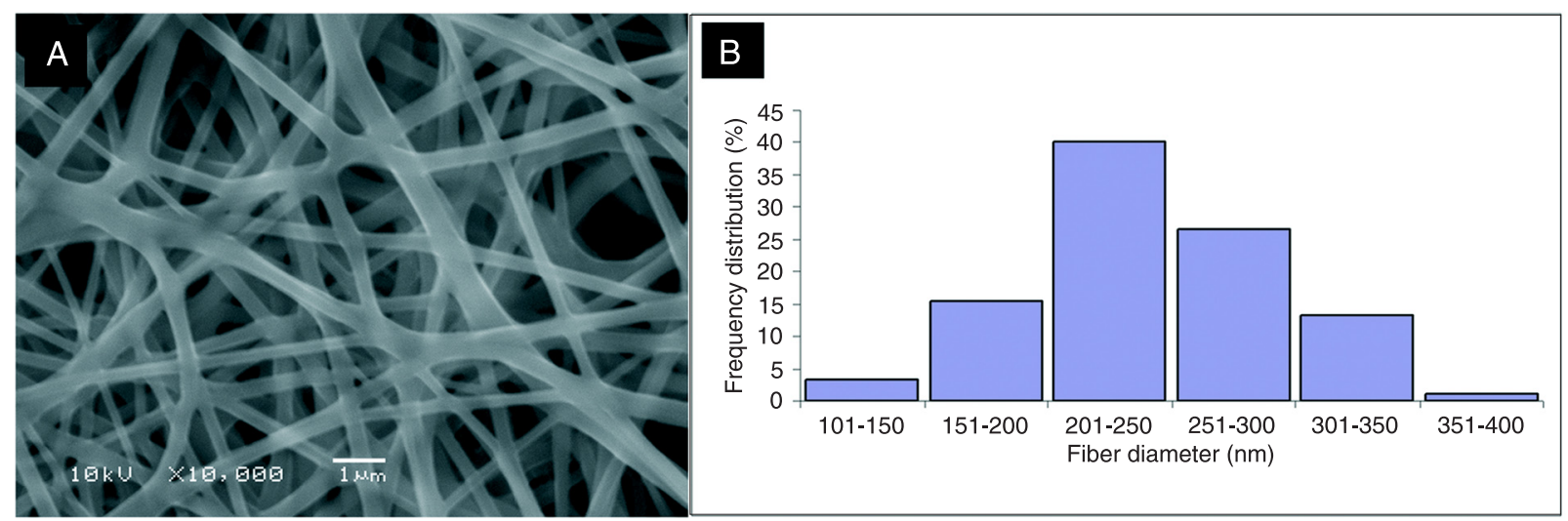

Figure 1. A, Scanning electron micrographs of nanofibers produced by electrospinning using PVA solution at a concentration of $10 \mathrm{wt} \%$ $(\mathrm{w} / \mathrm{v})$. B, Frequency of diameter distribution. Mean diameter $244 \pm 49 \mathrm{~nm}$.

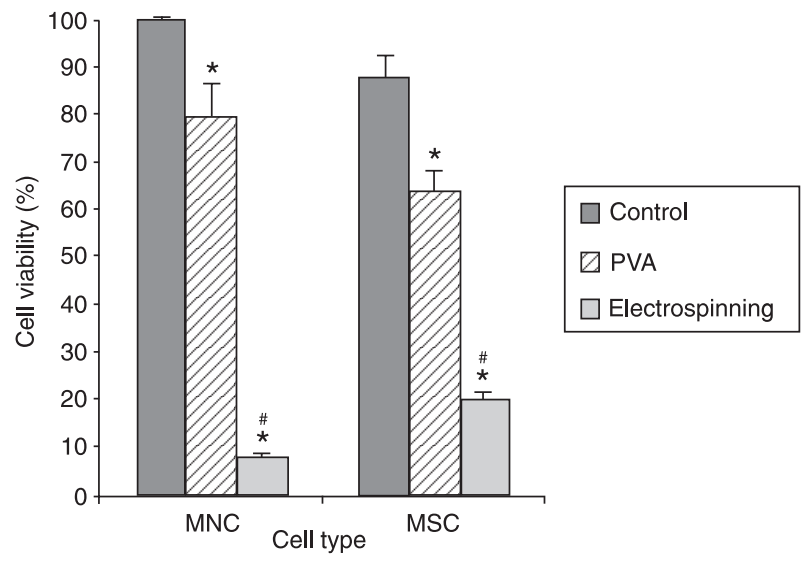

Figure 2. Cell viability after $30 \mathrm{~min}$ of treatment. Control = cells in culture medium; PVA = cells in $10 \%$ polyvinyl alcohol solution; electrospinning $=$ cells mixed with $10 \%$ PVA solution subjected to electrospinning. $\mathrm{MNC}=$ mononuclear cells; $\mathrm{MSC}=$ mesenchymal stem cells. Data are representative of three experiments carried out in triplicate and reported as mean cell viability $\pm S D$. ${ }^{*} P<$ 0.05 compared to control; \#P $<0.05$ compared to the PVA group (ANOVA followed by the Tukey test).

of viability from $88 \%$ in the control group to $64 \%$ when the cells were mixed with the PVAsolution. Analyses of the cells subjected to electrospinning showed a significant reduction in viability in both types of cells: experiments using MSCs showed $19.6 \%$ cell viability and experiments using MNCs showed $8.38 \%$ cell viability (Figure 2 ).

\section{Cell localization in scaffolds as the result of electrospinning}

Analysis of the distribution of MSC and MNC on the nanofiber scaffolds was performed using confocal laser scanning microscopy. The images suggested that the cells were not encapsulated by the fibers, probably because of the small fiber diameter, but rather that they were placed among the fibers, suggesting that they were distributed three-dimensionally in the scaffolds (Figure 3).

\section{Discussion}

In the present study, the influence of the electrospinning process and the solvent $10 \%$ PVA on MSC and MNC viability was analyzed. Electrospinning was performed at $21 \mathrm{kV}$ with a suspension of cells:PVA at a ratio of 1:12 (v:v). Using cells:PVA solution at a higher rate, fibers were not formed and only drops were observed on the collector plate, probably due to the reduction in polymer chain interaction because of the low viscosity. When a higher proportion of PVA solution was used, fibers were continuously produced, but as the concentration of cells decreased, the analyses of viability became hard to implement. These data agree with a recent study performed by van Aalst et al. (2), in which they used electrospinning to perform cell incorporation into nanofibers.

To assess cell viability after the electrospinning procedure, two different groups of cells from distinct sources were used. The first group was composed of MNCs, which are a heterogeneous population of cells obtained from UCB. These cells are of great interest for clinical procedures as they provoke less rejection in transplants and are easy to obtain without the need for a long-term process of cultivation or purification. Besides these advantages, it is known that there are a small number of stem cells among the fraction of MNCs (CD34+CD38- frequency = 0.05-0.08\%) (29), which are the cells responsible for the regeneration of damaged areas in tissue engineering. The second group of cells used was MSCs, isolated directly from the wall of the UC. Although this population demands a long period for isolation and cultivation, the use of a homogeneous population of MSCs seems to be more appropriate for the success of tissue engineering procedures. MSCs were collected from 

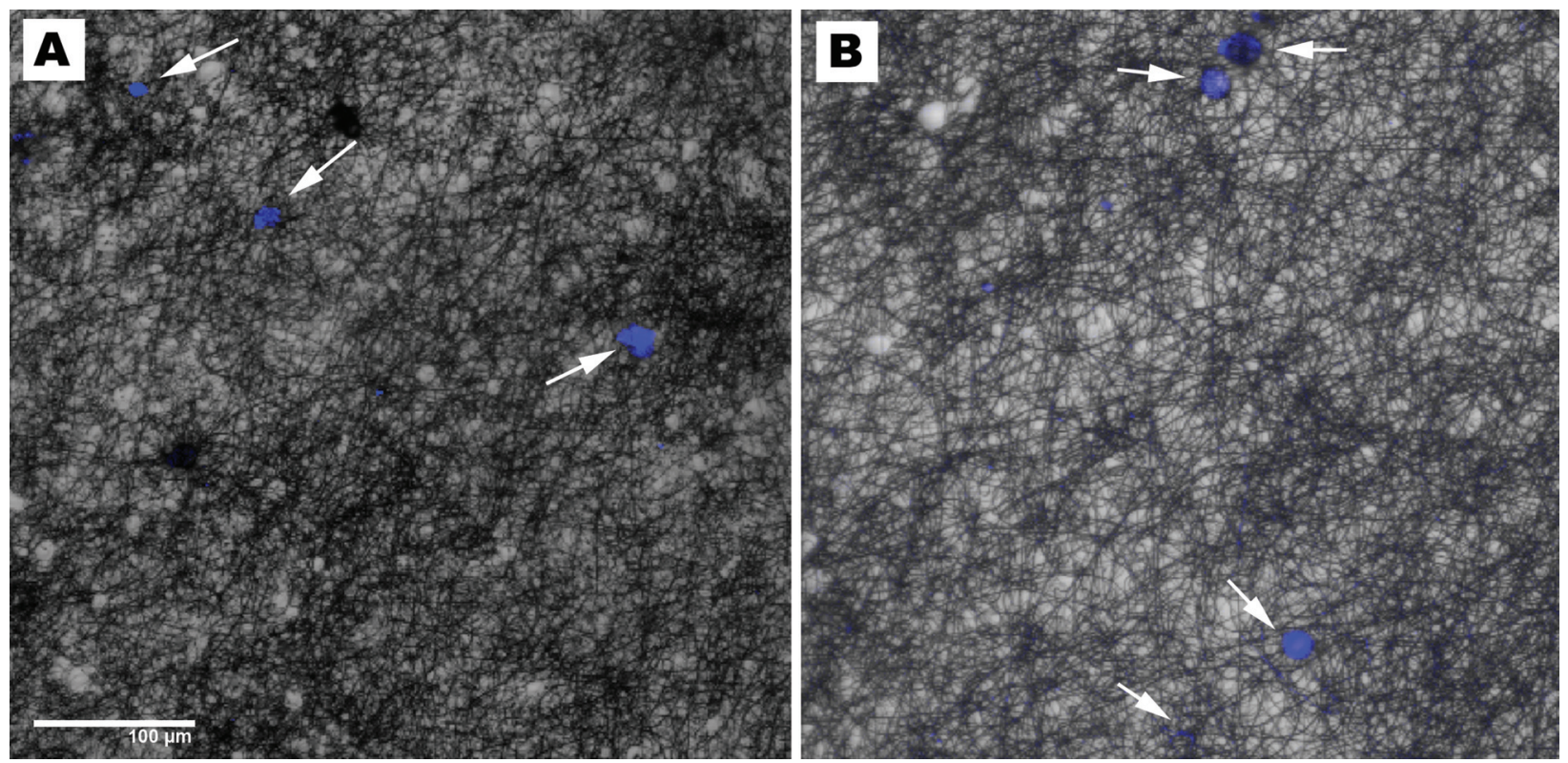

Figure 3. Images of confocal laser scanning microscopy showing cells among the fibers. $A$, Mononuclear cells. $B$, Mesenchymal stem cells. Arrows indicate cell nuclei. Nuclei stained with DAPI solution.

the wall of the UC instead of the UCB, as the number of these cells in the UC is greater than in UCB $(20,30)$.

Cells from the second group were analyzed for the presence of surface markers by flow cytometry and showed a classical profile of MSC markers $(20,24,25)$. The antigens CD146 (or Mel CAM) and Stro-1 are generally present in a small subset of MSCs (31). Only a small number of MSCs were positive for CD146 and these cells were negative for Stro-1.

Analyses performed after the cells underwent electrospinning showed a significant reduction in viability in both groups of cells, with $19.6 \%$ viability for MSCs and $8.38 \%$ viability for MNCs. In order to separate the toxic effect of the PVA from the cell damage caused by the electrospinning process, an experiment was performed to compare cells exposed to normal nutrient conditions (control group) and cells mixed in a solution of $10 \%$ PVA (PVA group). The results showed a statistical difference between the group of cells in the culture medium and the group of cells in the PVA solution, but no differences related to the type of cell used. The reduction of viability observed between the control and PVAgroups suggests that the PVA solution has

\section{References}

1. Iwasa J, Engebretsen L, Shima Y, Ochi M. Clinical application of scaffolds for cartilage tissue engineering. Knee Surg Sports Traumatol Arthrosc 2009; 17: 561-577.

2. van Aalst JA, Reed CR, Han L, Andrady T, Hromadka M, a deleterious effect on cells and that the decrease in cell viability during electrospinning could be caused, at least in part, by the lack of nutrients since as viscosity of the solution can prevent cells from coming into contact with the nutritive medium. In a recent study, van Aalst et al. (2), observed a reduction of viability of fibroblasts (30-65\%) and stem cells (22\%) after the electrospinning process and suggested that this could be explained by the high viscosity of the PVA solution, which changes the shearing effect on cells as they pass through the equipment (2).

Data suggest that PVA has potential as a candidate as a polymer vehicle during electrospinning as it is able to trap cells on the fibers and is easily soluble in an aqueous medium, promoting the fast release of the cells. Nevertheless, our results reinforce the importance of the fine control of the viscosity of the polymer solution to avoid the reduction in cell viability due to the lack of nutrients and the shearing stress during the electrospinning procedure.

\section{Acknowledgments}

The authors thank CNPq for financial support.
Bernacki S, et al. Cellular incorporation into electrospun nanofibers: retained viability, proliferation, and function in fibroblasts. Ann Plast Surg 2008; 60: 577-583.

3. Greiner A, Wendorff JH. Electrospinning: a fascinating 
method for the preparation of ultrathin fibers. Angew Chem Int Ed Engl 2007; 46: 5670-5703.

4. Stitzel J, Liu J, Lee SJ, Komura M, Berry J, Soker S, et al. Controlled fabrication of a biological vascular substitute. Biomaterials 2006; 27: 1088-1094.

5. Teebken O, Puschmann C, Rohde B, et al. Human iliac vein replacement with a tissue-engineered graft. Bern: Huber; 2009.

6. Thomas V, Jose MV, Chowdhury S, Sullivan JF, Dean DR, Vohra YK. Mechano-morphological studies of aligned nanofibrous scaffolds of polycaprolactone fabricated by electrospinning. J Biomater Sci Polym Ed 2006; 17: 969-984.

7. Sui G, Yang X, Mei F, Hu X, Chen G, Deng X, et al. Poly-Llactic acid/hydroxyapatite hybrid membrane for bone tissue regeneration. J Biomed Mater Res A 2007; 82: 445-454.

8. Schnell E, Klinkhammer K, Balzer S, Brook G, Klee D, Dalton $P$, et al. Guidance of glial cell migration and axonal growth on electrospun nanofibers of poly-epsilon-caprolactone and a collagen/poly-epsilon-caprolactone blend. Biomaterials 2007; 28: 3012-3025

9. Yang F, Murugan R, Wang S, Ramakrishna S. Electrospinning of nano/micro scale poly(L-lactic acid) aligned fibers and their potential in neural tissue engineering. Biomaterials 2005; 26: 2603-2610.

10. Zheng L, Sun J, Chen X, Wang G, Jiang B, Fan H, et al. In vivo cartilage engineering with collagen hydrogel and allogenous chondrocytes after diffusion chamber implantation in immunocompetent host. Tissue Eng Part A 2009; 15: 2145-2153.

11. Zhao G, Yin S, Liu G, Cen L, Sun J, Zhou H, et al. In vitro engineering of fibrocartilage using CDMP1 induced dermal fibroblasts and polyglycolide. Biomaterials 2009; 30: 32413250 .

12. Sahoo S, Ouyang H, Goh JC, Tay TE, Toh SL. Characterization of a novel polymeric scaffold for potential application in tendon/ligament tissue engineering. Tissue Eng 2006; 12: 91-99.

13. Lee $\mathrm{CH}$, Shin HJ, Cho IH, Kang YM, Kim IA, Park KD, et al. Nanofiber alignment and direction of mechanical strain affect the ECM production of human ACL fibroblast. Biomaterials 2005; 26: 1261-1270.

14. Subbiah T, Bhat GS, Tock RW, Parameswaran S, Ramkumar SS. Electrospinning of nanofibers. J Appl Polym Sci 2005; 96: 557-569.

15. Hromadka M, Collins JB, Reed C, Han L, Kolappa KK, Cairns BA, et al. Nanofiber applications for burn care. J Burn Care Res 2008; 29: 695-703.

16. Hohman MM, Shin M, Rutledge G, Brenner MP. Electrospinning and electrically forced jets. I. Stability theory. Physics of Fluids 2001; 13: 2201-2220.

17. Gluckman E, Broxmeyer HA, Auerbach AD, Friedman HS, Douglas GW, Devergie A, et al. Hematopoietic reconstitution in a patient with Fanconi's anemia by means of umbilicalcord blood from an HLA-identical sibling. N Engl J Med 1989; 321: 1174-1178

18. Lee OK, Kuo TK, Chen WM, Lee KD, Hsieh SL, Chen TH.
Isolation of multipotent mesenchymal stem cells from umbilical cord blood. Blood 2004; 103: 1669-1675.

19. Bieback K, Kern S, Kluter H, Eichler H. Critical parameters for the isolation of mesenchymal stem cells from umbilical cord blood. Stem Cells 2004; 22: 625-634.

20. Secco M, Zucconi E, Vieira NM, Fogaca LL, Cerqueira A, Carvalho MD, et al. Multipotent stem cells from umbilical cord: cord is richer than blood! Stem Cells 2008; 26: 146150.

21. Li X, Xie J, Yuan X, Xia Y. Coating electrospun poly(epsiloncaprolactone) fibers with gelatin and calcium phosphate and their use as biomimetic scaffolds for bone tissue engineering. Langmuir 2008; 24: 14145-14150.

22. Kazemnejad S, Allameh A, Soleimani M, Gharehbaghian A, Mohammadi $\mathrm{Y}$, Amirizadeh N, et al. Biochemical and molecular characterization of hepatocyte-like cells derived from human bone marrow mesenchymal stem cells on a novel three-dimensional biocompatible nanofibrous scaffold. J Gastroenterol Hepatol 2009; 24: 278-287.

23. Boudriot U, Goetz B, Dersch R, Greiner A, Wendorff JH. Role of electrospun nanofibers in stem cell technologies and tissue engineering. Macromolecular Symposia 2005; 225: 9-16.

24. Pranke P, Hendrikx J, Debnath G, Alespeiti G, Rubinstein $P$, Nardi N, et al. Immunophenotype of hematopoietic stem cells from placental/umbilical cord blood after culture. Braz J Med Biol Res 2005; 38: 1775-1789.

25. Dominici M, Le Blanc K, Mueller I, Slaper-Cortenbach I, Marini F, Krause D, et al. Minimal criteria for defining multipotent mesenchymal stromal cells. The International Society for Cellular Therapy position statement. Cytotherapy 2006; 8: $315-317$

26. Carrancio S, López-Holgado N, Sánchez-Guijo FM, Villarón E, Barbado V, Tabera S, et al. Optimization of mesenchymal stem cell expansion procedures by cell separation and culture conditions modification. Exper Hematol 2008; 36: 1014-1021.

27. Bernardi L, Luisi SB, Fernandes R, Dalberto TP, Valentim L, Bogo Chies JA, et al. The isolation of stem cells from human deciduous teeth pulp is related to the physiological process of resorption. J Endod 2011; 37: 973-979.

28. Meirelles Lda S, Nardi NB. Murine marrow-derived mesenchymal stem cell: isolation, in vitro expansion, and characterization. Br J Haematol 2003; 123: 702-711.

29. Pranke P, Failace RR, Allebrandt WF, Steibel G, Schmidt F, Nardi NB. Hematologic and immunophenotypic characterization of human umbilical cord blood. Acta Haematol 2001; 105: 71-76.

30. Panepucci RA, Siufi JL, Silva WA Jr, Proto-Siquiera R, Neder $\mathrm{L}$, Orellana $\mathrm{M}$, et al. Comparison of gene expression of umbilical cord vein and bone marrow-derived mesenchymal stem cells. Stem Cells 2004; 22: 1263-1278.

31. Yang X, Zhang W, van den Dolder J, Walboomers XF, Bian $Z$, Fan M, et al. Multilineage potential of STRO-1+ rat dental pulp cells in vitro. J Tissue Eng Regen Med 2007; 1: 128135. 